Mining Time in Sammy Baloji's Mémoire

Gabriella Nugent

University College London

Gabriella Nugent is a PhD candidate in History of Art at University College London.

Email: gabriella.nugent.14@ucl.ac.uk 
Mémoire, a series of photomontages constructed in 2006 by the Congolese artist Sammy Baloji, comprises a set of black and white archival photographs embedded onto colored prints of the contemporary landscape of Lubumbashi, a city located in the Katanga province of the Democratic Republic of Congo. This area was known for its colonial corporate copper mines. In the 30 composite images, Congolese men and women and European officials extracted from photographs produced mainly during the 1920s and 30s in the Belgian Congo appear to enter today's dilapidated industrial mining sites in and around the city.

The history of Katanga and the contemporary struggles in the region are central to the work of Sammy Baloji. The Berlin Conference of 1884-85 gave Katanga to the King of Belgium, Leopold II. Beneath its surface, Katanga concealed a geological wealth in copper. In addition to copper, the area contained zinc, cobalt, tin, gold, wolframite, manganese, tantalum, anthracite, coal, and uranium. Union Minière du Haut Katanga, a company established by King Leopold in 1906 and backed by Belgium's largest holding company, Société Générale de Belgique, exploited this wealth. ${ }^{1}$ The establishment of Union Minière followed virulent criticism of King Leopold over evidence of atrocities in his Congo Free State. ${ }^{2}$ This outcry led the Belgian Parliament to take control of the colony, changing its name to the Belgian Congo. Dependent on taxes produced by commercial enterprises, the state offered Union Minière continued access to Katanga (Fetter 1976; Vellut 1982). ${ }^{3}$ In 1910, Union Minière constructed a foundry and started to extract copper in 1911. Nearby, the city of Elisabethville, today Lubumbashi, was established. Union Minière exemplified "industrial paternalism" in its attempt to control every aspect of the workers' existence, from accommodation to schools, clubs, wives, health care, breastfeeding, and so on (Reid 1985; Hunt 1988). Independence slowly led to the end of the company. Under President Mobutu Sese Seko, Union Minière became state-owned in 1966 and had its name changed to Gécamines (Générale des Carrières et des Mines) as per the order of the government's authenticity program. Exhausted by 
Mobutu's extortions, Gécamines started to collapse in the 1980s. The company fell behind in its payment schedules, started laying off its workers and left its sites in disrepair, a course that accelerated in the 1990s. Unemployment currently overwhelms Katanga. ${ }^{4}$ Many men are now creuseurs or "artisanal miners," engaging in strenuous, dangerous activity lacking appropriate safety equipment. This current state of affairs is a significant break from the colonial past of industrial mining under high finance.

Born in 1978, Baloji grew up in Lubumbashi. He started photographing the city in 2004. Hubert Maheux, a curator at the city's French cultural center, provided Baloji with the equipment to take photographs for an architectural guide to Lubumbashi. Mémoire originates from Baloji's experience of photographing the city. A Belgian entrepreneur, George Arthur Forrest, who established the French cultural center, supported Baloji's early career. ${ }^{5}$ Forrest is the owner of Groupe Forrest, a conglomerate founded around the mining industry in Katanga in 1922 whose services vary from transport to civil engineering. Forrest was appointed an executive of Gécamines from 1999 to 2001 . He took this opportunity to acquire the archive of the former Union Minière. ${ }^{6}$ It was subsequently digitized. ${ }^{7}$ This archive along with others from government offices and organizations in Lubumbashi provided the black and white photographs which Baloji worked from in the series, digitally extracting figures and transposing them with Photoshop onto digital photographs taken by him of the contemporary sites.

Pertinent to Baloji's work is the influential notion of the "postcolony" as articulated by the Cameroonian philosopher Achille Mbembe in an eponymously titled collection of essays from 2001. For Mbembe, the "postcolony" expresses a given (and shared) trajectory - that of African societies emerging from the experience of colonialism with its concomitant violence (2001). He opened the collection with a scathing critique of the way in which the West characterizes Africa, arguing that the continent is primarily understood through conceptions of 
“'‘absence', 'lack' and 'non-being,' of identity and difference, of negativeness - in short, of nothingness" (2001: 4). This article argues that the "postcolony" as a construction is condemned to the very same "narrative of loss" that Mbembe decried (2001: 4). It has, paradoxically, been taken up by postcolonial scholars and conflated with Mbembe's thinking around "necropolitics and necropower" as summarized by him: "the various ways in which, in our contemporary world, weapons are deployed in the interest of maximum destruction of persons and the creation of death-worlds, new and unique forms of social existence in which vast populations are subjected to conditions of life conferring upon them the status of living dead" (2006:39-40). The "postcolony" has come to stand in recent theoretical literature for various states of absence, violence, and death. Baloji's work has previously been understood through such terms. Bogumil Jewsiewicki, for example, asserted that Mémoire expressed the feelings of loss experienced by Congolese youth due to the closure of the once prosperous mining sites (2010). It has become a "desolate wasteland" and Baloji, a "photographer of absence" (Jewsiewicki 2010: 8, 34). The sites' state of abandonment and disrepair was foregrounded by Tate Modern's wall text that accompanied the display of Mémoire in 2011 (Tate). Similarly, Elsie McCabe Thompson, the former President of the now closed Museum for African Art in New York, described Baloji's series as a once occupied environment, now characterized by an "absence of humanity" (McCabe in Jewsiewicki 2010: 7).

However, the aesthetics and politics of ruins and ruination are anything but static (Stoler 2013). The discourse of decline that circumscribes Mémoire tells only part of the story. Indeed, this approach is at odds with the complexity and nuances often explored in scholarship on Congo (Fabian 1971 and 1998; Hunt 1988 and 2016; Vellut 1983a; De Boeck and Baloji 2016). Dystopia, as discussed by Jennifer Robinson, is a profoundly disabling trope, one that overlooks a variety of experiences and moods in search of evidence to support an overarching and one-dimensional dystopic narrative (2010). This search for dystopia has circumscribed the 
vision of several scholars writing on Baloji's Mémoire. For, though the sites seen in the series are described by critics as abandoned or empty, on close inspection it appears that they are actually occupied by some contemporary figures. Men of varying ages, alone and in groups, congregate on the site captured in Untitled 17 (fig. 1). Dressed in casual clothes, they dig, stand by, crouch over and walk across the site. These appearances continue throughout the series asserting the environment as an occupied or populated one. Given that people continue to live in such environments, it is vital that we think more carefully about their existence and the terms of their visibility.

\section{Thinking through time}

Two color photographs of contemporary Lubumbashi are adjoined to compose the background or site in Untitled 3 onto which a group of men extracted from a black and white photograph are transposed (fig. 2). Naked with arms by their sides and buttocks exposed, the group is lined up for a physical examination on their arrival to Union Minière. ${ }^{8}$ Death and suffering had defined the camps where the workers lived in the early years of the company. Union Miniére was described by Jules Marchal as a "Man-Eating Corporation" (2003: 78). However, in the 1920s, the company attempted to stabilize its workforce. Union Minière started to offer longer contracts with the temptations of advance bridewealth payments, accommodation, schools, and care (Perrings 1979; Hunt 1988; Higginson 1989). Many Africans sought employment with the company (Fetter 1976; Vellut 1983b). Through the archival photographs and their juxtaposition with the dilapidated landscape, Baloji emphasizes a specific experience, the economic advantages Union Miniére workers enjoyed that were taken away after the end of colonialism. These advantages are occluded in several accounts on Union Miniére (Perrings 1979; Higginson 1989). John Higginson even suggested that the concerns of the workers were in continuous opposition to the company, clearly challenged by Baloji (1989). Higginson's 
assertion seems to constitute a larger trend in scholarship that overlooks the experience of Union Minière workers; the administration of the company is often more of a concern (Fetter 1976; Perrings 1979). ${ }^{9}$ Returning to the series, the examinations cited by the archival photographs in Mémoire were a component of Union Minière's strategy of stabilization as the company ascertained who was fit for work. Hygiene was considered crucial to a stable workforce. ${ }^{10}$ As Jean-Luc Vellut wrote, "The individual had become a unit of production, a tool" (1983b: 154).

The archival photographs employed by Baloji are embedded in the entwined traditions of photography and anthropology and the specific context in which they collide and coincide, that of Europe's colonial and industrial expansion and the concomitant encounter with otherness and labor. Photography's purported veracity was deployed during the late nineteenth century by a variety of scientific endeavors seeking claims of objectivity. However, the photographs themselves challenge such claims as they evince ways of seeing, constructing and experiencing the world according to time-bound conventions and systems of thought exterior to the photographs (Garb 2011). The archival photographs transposed to Mémoire are embedded in nineteenth-century thought, specifically conceptions of the black body as a legible or classifiable object of study and a site of curiosity (Green 1984). Arrayed frontally and horizontally for the camera, they parade their posed subjects as specimens or exemplars for scrutiny. But the convergence of photography and anthropology was afflicted by a sense of anxiety over what Deborah Poole called the "excessive detail" and "temporal contingencies" of photographs (2005: 164). Standardized arrangements of photographic subjects, she argued, were circulated from the 1880 s onwards in order to counter such excess and to subsume individuality to the type (2005). The men in the photographs used by Baloji exemplify this standardized system. Naked, formulaic and repetitive, the anonymous black male body appears captured and controlled by the camera. 
However, the photographs themselves simultaneously convey an excess of visual detail to that which the mining photographer had set out to capture. Turning to Untitled 3, one of the men in the group covers their sex, conveying a sense of vulnerability or anxiety inadvertently captured by the camera. In Untitled 1 (fig. 3), the group of men standing for the photograph gaze outwards, towards the camera and subsequently the viewer. Their gazes constitute a subversive site of encounter to the autonomy of the photograph, as the men appear to acknowledge the existence of the photographer and the camera (Lutz and Collins 1991). Time is occasioned through the apparatus of the camera as it is embedded in the advancements of technology. Similarly, the photograph's color, or lack thereof, conveys associations of time. Monochrome is now associated with a kind of technological obsolescence and a sense of veracity, operating as a site of opposition to the color overload of contemporary culture. Furthermore, the clarity and sharpness of the sites contrasts with the colonial photographs that appear softened, worn and sometimes even smudged. This collision enacts a temporal technological clash between a landscape preserved digitally and a scanned object of knowledge once circulated and exchanged as an analogue photographic print.

The anthropological genre that constructs the archival photographs is concerned with types, groups, and collective characteristics. The original archival photograph from Untitled 10 (fig. 4) appeared in a Union Miniére report entitled "Direction Generale: Rapport Trimestriel (Troisième Trimestre 1925)" that was promoted to Brussels. ${ }^{11}$ The text accounts for the activity of the company in July, August, and September of 1925, charting its overall administration, specific projects, surveys of the sites, and their associations with other organizations in Lubumbashi. There are eight photographs that appear two-a-side at the end of the report, varying from shots of the workers to the company's sites, specific equipment, and the officers' library. The photograph from Untitled 10 is second in the "photographies" section (fig. 5). Labelled with the glued text from a typewriter, it is entitled "Types d'indigènes 
Balovale" and taken in one of the camps, showing thatched structures, a tree from afar and couple of figures in the background. Underneath the photograph are the cursive words "Recrutements R. Miliamo" scribbled in red. There is a section of the report entitled "Recrutement dans les Territoires Occupés" to which the photographs presumably correspond. The text chronicles a successful expedition where Union Minière was able to enlist 211 workers. The writing goes on to typify the physical characteristics and comportment of the men: "type bon, sauf quelques indigènes du Ruanda d'un type mince, faible et élancé." In this context, the cloths that the men grasp onto are perhaps clothes they were given for work on their arrival to the site. The photograph above the one transposed to Untitled 10 captures a similar group of six men entitled "Types d'indigènes des terriotoires occupés" (fig. 6). There are two cooking containers on the ground, as if constructing a scene to convey the group's typical sustenance.

In Specters of the Atlantic, Ian Baucom charted the use of the type as one of the central acts of violence in an Atlantic system of speculative capital that was exemplified in the Zong atrocity, when in 1781, the crew of this slave ship threw 133 captives overboard in order for Captain Luke Collingwood to claim their insured value. Drawing on Walter Benjamin's conception of allegory, Baucom explained the way in which the slave was abstracted to a commodity. "Allegory," wrote Baucom, "enacts the central logic of commodification by conferring on its subject matter an abstract signification analogous to the economic value that capital processes of exchange confer upon the commodity" (2005: 9). From the commodity, the slave is abstracted again to a type of interest bearing money (2005). By throwing the slaves overboard, Captain Collingwood was hastening their transformation into money, a value that had been determined through the typicalizing mind of insurance (2005). Insurance is an enterprise through which the typical triumphs over the specific. The type is therefore, according to Baucom, "a refusal of the absolute, singular, individual, isolated lives of persons, events or 
things" (2005: 105). Indeed, the logic of the typical seems to occur again through the traces of text written on the surface of the archival photographs. However, through Baloji's extractions, the once legible text is obfuscated. Letters appear on the group in Untitled 3. Naked group shots similar to Untitled 3 are the only ones with writing on their surfaces. It is as if somebody had attempted to classify, categorize, or study the Congolese men after the photographs were taken in order to judge who was in good enough shape to work (Vellut 1983b). Doctors on the sites were asked to develop a sharp eye in order to reject medically unsuitable recruits (Vellut 1983b). They were looking for a certain type. The text, rendered illegible by Baloji, adds yet another layer to the series as the writing by the Union Minière official calls our attention to the surface of the original archival photographs.

Furthermore, the Congolese men montaged onto Untitled 3 were once ordered to shed their clothing for the camera, involving an act which was likely profoundly shame-producing at the time. ${ }^{12}$ For Congolese men and women, nakedness often conveys an experience of disempowerment (Jewsiewicki 2014). ${ }^{13}$ Under colonialism, African men were usually regarded as children who existed outside of time (Fabian 1983). Prior to the improvement of conditions at Union Minière and the days of the évolué (Fetter 1976), they were treated as what Didier Gondola calls "beasts of burden" in the expanding colonial economy (2016: 41). Masculinity was eventually constructed for the Congolese according to a sliding scale devised by the Belgian colonial government where savagery and civilization, tradition and modernity, "tribal" customs and European lifestyle constituted repulsive poles (Gondola 2016). Unsuccessfully, they attempted to enforce this totality onto the Congolese. However, through such violence as well as that of the effects of subsuming people to typologies, the extracted figures from the archival photographs - situated as they are in a contemporary landscape as if plucked from history - came to occupy time in an extraordinary way. Black men and women had to confront what Toni Morrison termed "“post-modern' problems," as in the alienating effects of capital 
and the shattering of the subject, already in the nineteenth century and earlier through the contexts of slavery and colonialism (Morrison in Gilroy 1993: 179). Drawing from Morrison, we may deduce that the group in Untitled 3 encountered the concerns that we associate with post-modernism already in the nineteenth century.

If time occurs in an exceptional way in the archival photographs, it also seems to travel. No photograph stands alone. Images exist simultaneously and offer a way to think through other photographs; to compare and contrast. The photographs in Mémoire accordingly speak to a wider archive of encounters with an oppressive state and its surveillance of work. They are charged with a kind of semantic contamination through the visual economy of photography. There is something about Mémoire that specifically contracts such entanglement. The photographs avoid any signifiers that give away a specific country. Unbound by title, they travel with ease through space and time. From Untitled 3, we are reminded of a comparable scene captured by Ernest Cole in apartheid South Africa of a group of miners subjected to a medical examination, arms extended and buttocks exposed (Cole 1967). The work similarly evokes photographs of aboriginal slaves taken towards the end of the 1800s in Australia; the shakedowns of convicts in the Texas Department of Corrections as seen in Danny Lyon's series from the 1960s (Lyon 1971); and the orders of colonial studio photography enforced across Africa (Garb 2014). In a single photograph are the traces of various others that preceded and succeeded it. They are connected through strains of colonial governance, enforced work, subjection, capitalism, and the Atlantic economy. Untitled 3 accordingly extends from the early 1900s to a series of other times that share the same conditions and are themselves available to viewers through the photograph.

The obvious conjunction of temporality in the series is the convergence of the colonial photographs with Baloji's photographs of the contemporary sites. However, even the contemporary is more fragmented and splintered than conventional knowledge would assume. 
Turning again to Untitled 3, we notice that the background is comprised of two prints that construct the site from varying degrees of closeness. In the photograph on the left, the space is shown from a wider angle. We see the entirety of the constructed and cleared ground, as if it was taken from an elevation. Mountains wrap around the expansive scene. In comparison, the adjacent photograph appears condensed. Trees crowd in on the space. Furthermore, the tarnished scraps of a railway transport system emerge. Up close, the once circular and working wheels are skewed and contorted and the train's color, corroded. Together, the two photographs construct the site, signifying the time of contemporary Lubumbashi onto which the colonial figures are transposed. Consequently, Mémoire shatters any sense of temporal coherence and wholeness, as the so-called "present-day" emerges as a time occupied and shared by several times.

Mémoire appears to convey the postcolonial experience of multiple temporalities, all of which occur concurrently alongside each other. ${ }^{14}$ Shaped by the complex experiences of Lubumbashi and Congo in general, time occurs through the orders of the body, the contexts and collisions of colonialism and the concerns and conventions of anthropology and photography. Time is seized and grasped in color and contemporary digitized culture, alongside the conflicting temporal connotations of analogue black and white. Time in Mémoire is entangled. The series captures the complexity of time in Lubumbashi.

\section{Time and colonialism}

The Belgian author David Van Reybrouck opened Congo: The Epic History of a People with an account of a 2008 visit to Étienne Nkasi, a Congolese man in Kinshasa. "Je suis né en millehuit cent quatre-vingt-deux," stated Nkasi (2014: 7). In disbelief, Van Reybrouck wrote: "Eighteen eighty-two? Dates are a relative thing in Congo. I have had informants tell me, when I asked how long ago something had happened: 'A long time ago, yes, a long, long time ago, 
at least six years, or no, wait, let's say: eighteen months ago"” (2014: 7). He observed: "My desire to provide a Congolese perspective would never be met with complete success: I myself am much too fond of dates" (2014: 7). In Van's Reybrouck's account, a clash occurs between a standardized European clock and a local Congolese sense of time. There is a Belgian, "much too fond of dates," and a descriptor, "a long, long time ago," seemingly in conflict with Nkasi's own time world. This confrontation in varying conceptions of time is embedded on the sites where Mémoire is set and suggested through the era of colonialism that the series invokes. For the colonial government had attempted to conscript the Congolese to Western structures, one of which was time (Mudimbe 1988; Mbembe 2005). The seven-day structure of the Christian week was enforced early on in the Kingdom of Kongo by the Portuguese (Balandier 1968). Nervousness, as articulated by Nancy Rose Hunt on the two Congo states, could create an experience of extreme surveillance in terms of time; even colonial administrators were asked about "where they slept, for how long, how they used funds, and speed in inspections" (2016: 102). Mines specifically were a site where autochthonous time was challenged and attacked, as employers like Union Minière were central to the spread of a standardized European clock (Ogle 2015). This enforcement of "clock time" through the structures of labor has been explored by E.P. Thompson (1968), Jean Comaroff and John Comaroff (1991) and Frederick Cooper (1992) in various geographical contexts. Money and time were explicitly equated (Thompson 1968; Comaroff and Comaroff 1991). The colonial government established the "time theory of value" in Congo whereby work was assessed in terms of time; wages were calculated by the hour (Mazrui in Kokole 1994: 46). Soon both employee and employer were supremely aware of "hours" per day and days per week of work for pay (Kokole 1994).

In an essay on time and colonialism in Africa, Alamin Mazrui and Lupenga Mphande observed: "Greater rigidity and greater supervision at the place of work in mining economies necessarily led to the African mine worker being more conditioned by the capitalist clock than 
his compatriot in the agricultural sector" (1994: 98). There was a stringent European time schedule enforced onto the workers by Union Miniére (Fetter 1976). The archival photographs employed by Baloji in Untitled 18 and Untitled 29 were originally situated in a document entitled "Travail rédigé en 1929” that explores the activity of a Union Minière worker in 1929. The chapter that chronicles their typical day is structured through constant temporal signifiers. This obsession with time at Union Minière has been previously discussed by Hunt as the company attempted to control the time of workers' wives in order to alter African birth spacing customs, which were viewed by mine owners and officials as a kind of birth control (1988). Breastfeeding and weaning were scheduled in order to reduce birth intervals. Feeding older children above the age of one was also a company affair scheduled two to three times a day. As expressed by Bruce Fetter, the Union Minière "management decided to 'breed' its own labor force" (1986: 466). The text in "Travail rédigé en 1929" exposes a similarly stringent structure. The workers comply to a standardized European clock: "Il est deux heures," "cinq heures," "six heures," and "six heures et demie." A siren sounds every day at six thirty. If the workers are slow to wake, the guards clamor. There is a second siren to signal that work is about to start and a third at seven o'clock. Immediately after the siren, the attendance is taken. The sounds of the gong signify the start of class for children and the availability of water. In the afternoon, a siren occasions the stopping of work for lunch in the cafeteria. The gongs, sirens and calls of the guards that splinter the air of Lubumbashi convey a time world in a state of shift, of shattering sounds that conscript the spins of the earth. They are the aural components of colonialism's violence that effected, according to Frantz Fanon, a cultural obliteration, charting a transformation in space and time (1965).

However, the figures transplanted from the archival photographs attest to something else. At the very least they testify to a continued existence or occupancy of the land. Grounded in the space that constructs Mémoire, the worker's shoes in Untitled 9 (fig. 7) stand aligned 
with the surface of the earth. In Untitled 11 (fig. 8), the group's soles are exposed to the warmth of the ground and the coarse textures of jagged stones. Meanwhile, the sun casts the archival figures' shadows across the sites where they were once employed, echoing the surrounding physical structures. They appear as tangibly and physically present as the wire, steel, and concrete that surrounds them. More than just being there, the archival figures appear in Baloji's series as active occupiers of the landscape, tending to the site and still working the land. Men dig, equipped with shovels; their waists submerged in the earth (fig. 9). Discussing the series, Baloji stated: "For Congolese people, the dead are not dead at all. They are still with us" (Baloji). There exists an uncanny encounter set up in the series between the archival workers and the contemporary occupants of the space. Mazrui and Mphande characterized the way in which the dead continued to exist and affect the living as evidence of a certain kind of temporality (1994). They contended that prior to the imposition of the capitalist clock, there was more of an orientation toward concrete activities and events already experienced (1994). Like the ancillary figures in the contemporary landscape, "their past was inextricably connected with their present" so to speak (Mazrui and Mphande 1994: 98). In Mémoire, the archival workers are extracted, cropped and severed from one time, that of colonial and analogue black and white technologies, and enter another, color and contemporary culture. Soil the color of sand clashes with the ground of a compound in the early 1900s captured in shades of grey; cloths from same era catch the sun of the contemporary landscape (fig. 4). The time across the sites seems oriented towards the early 1900s, which appears in the series as entangled with the contemporary. This orientation stands in opposition to the temporality that capitalism enforced, as in, according to Mazrui and Mphande, the spread of a time world whereby "man is always moving 'forward' toward the future" (1994: 99). The capitalist clock entered spaces where a smaller degree of emphasis had existed on what was to come or on endless tomorrows 
(Mbiti 1990). Thus, the archival figures in the landscape could be seen as a continuation of an alternative time world to that of the capitalism. ${ }^{15}$

\section{Holding on}

Muscles are tensed in Untitled 10. Brows are wrinkled, and jaws are clenched. Nostrils expand while lips are pressed together. Taut skin stretches over the men's chests. In Untitled 3, the men's buttocks are clenched. Indentations appear on either cheek. In Untitled 9, the worker stands erect for the camera. In each of the photographs, the men's arms are stiffly suspended alongside their sides. Far from expressions of ease or comfort, these are shots enacted through orders. "The native's muscles are always tensed," Frantz Fanon observed (1965: 53). He continued: "You can't say that he is terrorized or even apprehensive. He is in fact ready at a moment's notice to exchange the role of the quarry for that of the hunter" (1965: 53). Drawing from Fanon, Darieck Scott explored the trope of "muscular tension" to articulate the experience of the colonized (2010). Muscular tension, according to Scott, offers a space from which to think about other forms of possibility as in "the potential of transformation in however limited, constrained, or attenuated a configuration" (2010: 58) It is about an effective capability, an opposition expressed through what Scott called "a refusal to give defeat any final acceptance, a refusal to acquiesce to it" (2010: 63). Such contractions suggest a "reservoir of resistance" to the colonizer's acts of subjugation (2010: 65). The workers in Katanga were not simply a blank page upon which successive phases of industrial expansion and social engineering could impose themselves (Higginson 1989).

In the document "Travail rédigé en 1929," where the archival photographs from Untitled 18 and Untitled 29 were originally situated, there is a chapter entitled "stabilisation" that chronicles the company's attempt of stabilization in the 1920s. The text contains several accounts of various workers who visited their villages and chose to return to Union Minière. 
There are even some who enlisted others from their village for work. They are accordingly stabilized - "Il est stabilisé." The chapter champions examples of stabilization that set workers up as family men with wives and children. The subtext is a kind of exemplary colonization that occurs as the workers actively choose Union Minière, "l'equipe sanitaire" and "le lit" over the contexts from which they originate. There is an ease conveyed in the writings of the stabilizations that apparently transpired effortlessly. However, the archival photographs employed by Baloji suggest something else. Men are seen in various states of tension - with clenched jaws and taut skin. As workers, they were the primary line of defense for their own cultural practices as they came into contact with the aggressions of sirens, gongs, and the calls of guards. ${ }^{16}$ Indeed, we could speculate, that in the men's wrinkled skin, stiffened arms, and contracted thighs, there exist other temporalities onto which they grasp.

Let us return a final time to the scholarship on Mémoire. The series is often understood through conceptions of absence. Scholars close it off as a space that only generates states of lack. Baloji's series is consigned to a predictable, straightforward analysis, the staging as a shallow spectacle of the vestiges of colonialism and tyrants in the postcolonial wake who chart a straightforward trajectory from King Leopold and colonial greed to the ongoing effects of exploitative global capitalism (Hunt 2016). Obsessed with surfaces, appearances, sensational events, and simplistic categorizations, these accounts of Mémoire confirm conceptions of a depleted colony and a deathly "postcolony." The scholarship employs metaphors of mourning through lamenting the deadly empty space conveyed in Mémoire as if it was a graveyard only inhabited by the ghosts of the past (De Boeck and Plissart 2004). However, across the series, there is an excess of time and geographical space through montaged images that complicate such reductions. Baloji's works offer more than their surface appearances might suggest. There is always something else, something more going on in these so-called "dystopic" spaces, as the 
complexity of the archival layers in the photographs attest. Life takes shape in varying configurations, through stilled figures and supposedly empty backgrounds, all too easily dismissed and overlooked. The series calls for a closer engagement with maligned spaces in order to convey the complexity of historical, quotidian, and entangled experiences and the contradictions invoked by abandoned yet also patently occupied sites. For the rubric of time turns our attention to the lived-in quality of these landscapes, as it was then and it is now.

\section{References}

Balandier, Georges. 1968. Daily Life in the Kingdom of the Kongo: From the Sixteenth to the Eighteenth Century, trans. by Helen Weaver. London: George Allen \& Unwin Ltd.

Baloji, Sammy. 2015. "Sammy Baloji: The Past in Front of Us." Vimeo. https://vimeo.com/132212385 (accessed 6 March 2018).

Baucom, Ian. 2005. Specters of the Atlantic: Finance Capital, Slavery, and the Philosophy of History. Durham and London: Duke University Press.

Braeckman, Colette. 2009. Vers la deuxième indépendance du Congo. Brussels: Le Cri Edition.

Campt, Tina. 2017. Listening to Images. Durham: Duke University Press.

Cole, Ernest. 1967. House of Bondage. New York: Random House.

Comaroff and Comaroff, Jean and John. 1991. Of Revelation and Revolution: Christianity, Colonialism and Consciousness in South Africa. Chicago and London: The University of Chicago Press.

Cooper, Frederick. 1992. "Colonising Time: Work Rhythms and Labour Conflict in Colonial Mombasa." Colonialism and Culture, ed. Nicholas B. Dirks, pp. 209-245. Ann Arbour: University of Michigan.

De Boeck, Filip and Marie-Françoise Plissart. 2004. Kinshasa: Tales of the Invisible City. Leuven: Leuven University Press.

De Boeck, Filip and Sammy Baloji. 2016. Suturing the City: Living Together in Congo's Urban Worlds. London: Autograph ABP.

Demos, T.J. 2013. Return to the Postcolony: Specters of Colonialism in Contemporary Art. Berlin: Sternberg Press.

Fabian, Johannes. 1971. Jamaa. Evanston: Northwestern University Press. 
Fabian, Johannes. 1983. Time and the Other: How Anthropology Makes its Object. New York: Columbia University Press.

Fabian, Johannes. 1998. Moments of Freedom: Anthropology and Popular Culture. Charlottesville and London: University Press of Virginia.

Fanon, Frantz. 1965. The Wretched of the Earth, trans. Constance Farrington. New York: Grove Weidenfeld.

Fetter, Bruce. 1976. The Creation of Elisabethville 1910-1940. Stanford, California: Hoover Institution Press.

Fetter, Bruce. 1986. "Relocating Central Africa's Biological Reproduction, 1923-1963." The International Journal of African Historical Studies 19 (3): 463-475

Garb, Tamar. 2011. Figures and Fictions: Contemporary South African Photography. London: Victoria and Albert Museum.

Garb, Tamar. 2014. Distance and Desire: Encounters with the African Archive. Göttingen, Germany: Steidl.

Gilroy, Paul. 1993. Small Acts: Thoughts of the Politics of Black Cultures. London: Serpent's Tail.

Gondola, Ch. Didier. 2016. Tropical Cowboys: Westerns, Violence, and Masculinity in Kinshasa. Indianapolis: Indiana University Press.

Green, David. 1984. "Veins of Resemblance: Photography and Eugenics". Oxford Art Journal 7 (2): 3-16.

Higginson, John. 1989. A Working Class in the Making: Belgian Colonial Labour Policy, Private Enterprise, and the African Mineworker, 1907-1951. Madison: The University of Wisconsin Press.

Hunt, Nancy Rose. 1988. “"Le Bebe en Brousse': European Women, African Birth Spacing and Colonial Intervention in Breast Feeding in the Belgian Congo." The International Journal of African Historical Studies 21 (3): 401-432.

Hunt, Nancy Rose. 2016. A Nervous State: Violence, Remedies, and Reverie in Colonial Congo. Durham and London: Duke University Press.

Jewsiewicki, Bogumil. 2010. The Beautiful Time: Photography by Sammy Baloji. New York: Museum for African Art.

Jewsiewicki, Bogumil. 2014. "Denial and Challenge of Modernity: Suffering, Recognition, and Dignity in Photographs by Sammy Baloji." Suffering, Art and Aesthetics, ed. M.

Nijhawan and R. Hadj-Moussa, pp. 51-74. New York: Palgrave Macmillan. 
Kokole, Omari H. 1994. "Time, Language and the Oral Tradition: An African Perspective". Time in the Black Experience, ed. Joseph K. Adjaye, pp. 35-54. London and Westport, Connecticut: Greenwood Press.

Lutz, Catherine and Jane Collins. 1991. "The Photograph as an Intersection of Gazes: The Example of National Geographic." Visual Anthropology Review 7 (1): 134-149.

Lyons, Danny. 1971. Conversations with the Dead. New York: Holt, Rinehart and Winston.

Marchal, Jules. 2003. Forced labor in the gold and copper mines: a history of Congo under Belgian rule, 1910-1945, trans. Ayi Kwei Armah. Popenguine, Senegal: Per Ankh.

Mazrui, Alamin and Lupenga Mphande. 1994. "Time and Labor in Colonial Africa: The Case of Kenya and Malawi”. Time in the Black Experience, ed. Joseph K. Adjaye, pp. 97-119. Westport, Connecticut and London: Greenwood Press.

Mbembe, Achille. 2001. On the Postcolony. Berkeley and Los Angeles, CA and London: University of California Press.

Mbembe, Achille. 2005. "Variations on the Beautiful in the Congolese World of Sounds." Politique Africaine 100 (4): 69-91.

Mbembe, Achille. 2006. "Necropolitics." The Unhomely: Phantom Scenes in Global Society, trans. Libby Meintjes, ed. Okwui Enwezor, pp. 32-51. Seville: BIACS.

Mbiti, John. 1990. African Religions and Philosophy. Oxford: Heinemann.

Mudimbe, V.Y. 1988. The Invention of Africa: Gnosis, Philosophy, and the Order of Knowledge. Bloomington and Indianapolis: Indiana University Press.

Nzongola-Ntalaja, Georges. 2002. The Congo From Leopold to Kabila: A People's History London and New York: Zed Books.

Ogle, Vanessa. 2015. The Global Transformation of Time: 1870-1950. Cambridge, MA: Harvard University Press.

Perrings, Charles. 1979. Black Mineworkers in Central Africa: Industrial Strategies and the Evolution of an African Proletariat in the Copperbelt, 1911-41. New York: Africana Publishing.

Poole, Deborah. 2005. "An Excess of Description: Ethnography, Race, and Visual Technologies.” Annual Review of Anthropology 34: 159-179.

Reid, Donald. 1985. "Industrial Paternalism: Discourse and Practice in Nineteenth-Century French Mining and Metallurgy." Comparative Studies in Society and History 27 (4): 579607.

Robinson, Jennifer. 2010. "Living in Dystopia: Past, Present, and Future in Contemporary African Cities." Noir Urbanisms: Dystopic Images of the Modern City, ed. Gyan Prakash, pp. 218-240. Princeton, NJ: Princeton University Press. 
Stoler, Ann Laura. 2013. “"The Rot Remains': From Ruins to Ruination.” Imperial Debris: On Ruins and Ruination, ed. Ann Laura Stoler, pp. 1-35. Durham: Duke University Press.

Thompson, E.P. 1968. The Making of the English Working Class. Harmondsworth: Penguin.

Tate Modern. "Contested Terrains: Sammy Baloji." http://www.tate.org.uk/whats-on/tatemodern/display/level-2-gallery-contested-terrains/contested-terrains-sammy-baloji (accessed 6 March 2018).

Van Reybrouck, David. 2014. Congo: The Epic History of a People, trans. Sam Garrett. London: Fourth Estate.

Vellut, Jean-Luc. 1982. "Hégémonies en construction: Articulations entre Etat et Entreprises dans le bloc colonial Belge (1908-1960)." Revue canadienne des études africaines/Canadian Journal of African Studies 16(2): 313-330.

Vellut, Jean-Luc. 1983a. "Le Katanga industriel en 1944: Malaises et anxiétés dans la société colonial." Le Congo belge durant la Seconde Guerre Mondiale, pp. 495-523. Brussels: Académie Royale des Sciences d'Outre-Met.

Vellut, Jean-Luc. 1983b. "Mining in the Belgian Congo." History of Central Africa, eds. David Birmingham and Phyllis M. Martin, pp. 126-162. Longman: London and New York.

\footnotetext{
${ }^{1}$ Union Minière was also backed by the British company Tanganyika Concessions (Fetter 1976).

${ }^{2}$ The British journalist E.D. Morel led a campaign that started in the 1890s against slavery in Congo Free State after observing a discrepancy in trade statistics while working as a clerk in Liverpool for Elder Dempster, a shipping firm who had the contract for carrying all cargo to and from Congo. After several years of campaigning, Morel succeeded in putting the "Congo Question" on the British agenda. The House of Commons passed a resolution urging that Congo "natives should be governed with humanity". The British consul in Congo, Roger Casement, was subsequently sent up country for an investigation. His 1904 report confirmed Morel's accusations and had a considerable impact on public opinion. By offering attractive investments through the consortiums, for example, Union Minière, Leopold had hoped to gain the support of financiers and, through them, to gain sympathy from their governments (Fetter 1976).

${ }^{3}$ However, the colonial state was never able to take advantage of its position inside the governing bodies of big companies nor was it able to participate effectively in the planning of development strategies that would affect the future of the colony (Vellut 1982).

${ }^{4}$ In 2003 Gécamines, at the insistence of the IMF and the World Bank, had fired eleven thousand superfluous workers (Braeckman 2009).

${ }^{5}$ Forrest's investments in the Lubumbashi cultural scene have since only intensified. The center has made major efforts to position Lubumbashi within a more global arts context through the Pincha Biennial, which has been curated by well-known figures such as Simon Njami in 2010 and Elvira Dyangani Ose in 2013.

${ }^{6}$ The archive of Union Miniére consists of various trimestral and annual reports of the company's activity, many of which were sent to Brussels. The photographs were produced to advocate the efficient workings of the company. They often appear in their own section after the text. For example, a group of workers standing for vaccinations are seen alongside shots of the school and other architecture on the compounds.

${ }^{7}$ At Baloji's suggestion and with the Malta Forrest Foundation's financial support, Maheux had them digitized.

${ }^{8}$ Medical inspection was essential in the recruitment process. Union Minière required examinations both on enlistment and on arrival at the place of work. Only robust and healthy individuals were admitted to the compounds. (Vellut 1983b)

${ }^{9}$ These accounts are largely preoccupied with the implementation of a Marxist analysis (Higginson 1989; Perrings 1979).
} 
${ }^{10}$ High mortality among first recruits had shown that, without socialized medicine, companies could not bear the cost of maintaining a workforce. The motto, 'good health, good spirits and high productivity', was set forth by Union Minière in 1927 (Vellut 1983b).

${ }^{11}$ My archival research was conducted at the Belgian National Archives 2 - Joseph Cuvelier.

${ }^{12}$ In rural central African society, an adult man stripped in public loses all respect, all status (Jewsiewicki 2014).

${ }^{13}$ This is not always the case; there is a long-standing tradition of women from many different African states resorting to naked protest.

${ }^{14}$ In On the Postcolony, Mbembe writes: "As an age, the postcolony encloses multiple durées made up of discontinuities, reversals, inertias, and swings that overlay one another, interpenetrate one another, and envelope one another: an entanglement" (2001:14).

${ }^{15}$ Indeed, earlier conceptions of time continued to exist. This is suggested by Hunt as Congolese women rejected nursing their infants according to a tight and regular time schedule and continued to nurse them at night (1988). Similarly, Balandier attests to the retention of the Kongo week in the face of Christianity as the former regulated traditional cults, which occurred alongside "the religion of Sunday," and governed the economic week (1968). My emphasis on the specificity of time is a case against recent literature that comprehends temporality in the postcolony solely through Derridean ghosts (Demos 2013).

${ }^{16}$ I am indebted to Tina Campt's exploration of "muscular tension" apropos Scott in the context of the archives from Marianhill Mission, a colonial monastery on the Eastern Cape of South Africa (2017). 